\title{
Symopsis of the North American species belonging to the Genera LEUCOSPIS, SMICRA and CHALCIS.
}

\author{
BY E. T. CRESSON.
}

Genus LEUCOPSIS, Fabr.

Abdomen petiolate. bulbiventris.

Abdomen sessile or subsessile.

Body black, immaculate, without metallic lustre; wings black, hyaline at tip apicalis.

Body black, immaculate, with a green metallic lustre; wings hyaline.

Abdomen green-sericeous at apex; the ovipositor reaching to the apex of scutellum

mexicana.

Abdomen bright golden at apex; ovipositor not reaching to base of second abdominal segment

Sumichrastii.

Body more or less marked or banded with yellow or red:

Abdomen short, broad, much narrowed at base; posterior femora very large, broadly margined above with yellow; abdomen with two or three yellow bands; wings fuliginous.

texana.

Abdomen elongate, not much narrowed at base :

Ovipositor long, reaching to base of abdomen :

Prothorax with lateral and posterior margins broadly yellow; scutellum almost entirely yellow; the $q$ with apex of abdomen ferruginous................................................................. Poeyi.

Prothorax with lateral and posterior margins narrowly yellow ; scutellum narrowly yellow at apex

aflinis.

Prothorax with lateral and posterior margins red; scutellum red at apex

floridinan.

Prothorax with posterior margin only narrowly yellow; scutellum narrowly yellow at apex :

Apex of abdomen broadly yellow; posterior femora with a yellow stripe beneath azteca.

Apex of abdomen and posterior femora entirely black..... dubiosa. Ovipositor short, not reaching to base of second abdominal segment; prothorax with two yellow bands; seutellum immaculate; abdomen with a silvery band at apex of second and third segments..tolteca.

\section{Leucopsis bulbiventris, $n$. sp.}

$\widehat{\delta}$.-Black, densely puncturêd, more or less tinged with green and purple; head small, not wider than thorax, face purplish, clothed with short whitish pubescence; antennæ ——, the antennal grooves very deep and bright metallic green; mandibles small, robust, reddish at base; prothorax with a narrow, interiupted, yellowish band near posterior margin: mesothorax more obviously green over tegulæ, posterior margin narrowly yellow; scutellum broad, sub. quadrate, immaculate; postscutellum small, flat, transverse, rounded posteriorly, smooth and shining; metathorax green, with a patch of dense silvery seri- 
ceous pubescence on each side behind each posterior wing; tegulæ piceous; wings yellowish, dusky on costal margin, especially beyond stigma; legs short, tips of anterior femora within, their tibiæ within and their tarsi pale yellowish; intermediate legs — ; upper edge of the posterior coxæ, a spot beneath at tip, a spot on trochanters beneath, upper edge of their femora, a line beneath before the teeth, dilated basally, a stripe on their tibiæ behind, not reaching the base, and their tarsi, pale yellow; femora small, ovate, polished within, teeth numerous and minute except the basal one which is largest; abdomen as long as head and thorax, clavate, being slender at base and much swollen at apex, incisures of segments indistinct; first segment narrow, slightly dilated and convex at base and somewhat contracted before apex; second segment narrowed at base, the apex of the third (?) margined with silvery sericeous pubescence; fourth (?) segment with dense silvery sericeous pile, converging towards the disk: apical segment very small. Length .47 inch.

Mab.-Mexico. One specimen collected by Prof. F. Sumichrast. The shape of the abdomen recalls that of some species of the Dipterous genus Conops, although rather more strongly clavate.

\section{Leucospis apicalis, n. sp.}

9.-Dull black, tinged with brownish, densely punctured, face with short silvery pubescence, clypeus, mandibles and scape beneath pale ferruginous; prothorax at sides and pesterior margin more or less brown ferruginous, a transverse raised, sometimes pale line before posterior margin ; scutellum brownish posteriorly; metathorax with pale golden pubescence; tegulæ dull fulvous; wings blackish, apical third hyaline; legs more or less tinged with brown, posterior fernora immaculate, with about nine short, robust, obtuse teeth; abdomen elongate, slightly compressed at tip, subsericeous, immaculate, more or less tinged with brownish, especially at apex, densely punctured, shining laterally; ovipositor reaching to tip of scutellum. Length .40 inch.

Hab.-Mexico. Prof. Sumichrast. Two specimens. Easily recognized by the immaculate dull black body and the blackish wings tipped with hyaline.

\section{Leucospis mexicana.}

Leucospis mexicana, Walk. Jour. Ent. i, p. 20, $\subsetneq$.

Hab.-Mexico. Prof. Sumichrast. Three $q$, one $\delta$, specimens. The thorax and apex of abdomen of $q$ is strongly metallic green, clothed with short pale sericeous pile; face pale ferruginous, with a silvery pubescence, as well as posterior orbits; a band of pale silvery green pubescence behind scutellum; bas of abdomen with a smooth polished excavation; posterior coxæ smooth and polished on the outer flat surface; their fomora with six to eight small teeth beside the large obtuse basal tooth. The $\delta$ seems to accord tolerably well with Westwood's description and figure of Metallopsis cayennensis (Germar Zeits. Ent. i, p. 264, pl. 4, fig. 4). The face is pale reddish as in $q$, with a cupreous reflection, while the body is more 
brilliantly green, especially the abdomen, the apex of which is golden green and somewhat depressed, the very large second segment has a fine, central longitudinal carina on its entire length; the legs are tinged with brown, the posterior femora margin above and beneath from and including the large tooth, to the base, with yellow as in the $q$, their tibiæ are redish at tips, with a yellow line behind reaching to basal third; the antennal grooves are deep and bright eupreous. Length of $q, .30-.45$; of $\delta, .35$ inch.

\section{Leucospis Sumichrastii, n. sp.}

9.- Short, broad, densely punctured, black, more or less tinged with metallic green; face and posterior orbits with a fine silvery pile; occiput flat, trassversely striated, bright green, bounded above by a sharp carina; antennæ black, scape above and base of flagellum beneath ferruginous, scape yellowish beneath; prothorax broad, dull black; scutellum broad, with a smooth shining spot on apical middle; metathorax above pale ferruginous, clothed with a dense silvery-white pubescence; tegulæ piceous; wings hyaline, the costa, narrowly beyond stigma, continued more broadly on upper half of apical margin, fuscous; four anterior tibiæ tinged with ferruginous within, tips of posterior coxæ above, and narrow upper and lower margin of their large femora, not quite reaching apex beneath, pale yellowish, the band beneath from large tooth to base rather broad, the small teeth about eight in number; posterior tibiæ reddish behind; abdomen with first segment narrower than the second, nearly quadrate, smooth, polished and deeply excavated at base, apex thickly punctured; base of second segment contracted, this segment finely and densely punctured, the apex broadly margined with a dense bright golden pubescence; apical segment, except at base, clothed with a dense bright golden pubescence and when viewed laterally is interrupted on each side of middle by a longitudinal greenish stripe; ovipositor short, porrect, not exceeding in height that of the second segment, although the groove extends nearly to the base of the segment. Length .32 inch.

Hab.-Mexico. Prof. Sumichrast. One specimen. A short robust form, easily distinguished by the abdomen being ornamented with bright golden at apex.

\section{Leucospis texana, n. sp.}

$\delta$.-Black, opaque, with a rather dense pale sericeous pubescence and large dense punctures; two obscure reddish spots on middle of face; mandibles and palpi rufo-piceous; antennæ reddish, black at tips, scape yellow; two spots behind antennæ, posterior margin of prothorax, line over tegulæ, posterior margin of scutellum, small spot beneath wings and an oblique line on each extreme side of metathorax, also yellow ; sides of prothorax and tegulæ pale ferruginous; wings fuliginous; legs ferruginous, anterior coxæ, a stripe on each side of their femora, base of intermediate femora, and posterior coxæ above and at base be. neath, black; four anterior knees and tibiæ in front yellowish; posterior femora very large, almost circular, a large blackish stain on inner side and a large black spot on outer side, broadly margined above with yellow, and a yellow spot beneath near base, armed beneath with three very large, long, distant 
rather sharp, black teeth and near apex a smaller blunt one, beyond which are two or three minute serratures not distinctly defined; posterior tibiæ yellow posteriorly; abdomen short, subglobose, narrowed at base, extreme base smooth and rufo-piceous; a narrow band near base, two broader approximate bands, sometimes confluent, near apex, and a lunate spot at apex surmounting an oblong smooth depressed space, yellow. Length .30 inch.

Hab.-Texas. (Belfrage.) Two specimens. This has a remarkably short, robust form, different from that of any of the other species, and approaching more nearly to that of Sumichrastii, although quite different. The very large, almost circular, posterior femora, with only four distinct teeth, three of which are long, slender and acute, readily distinguish it from any other North American species.

\section{Leucospis Poeyi.}

Leucospis Poeyi, Guér. Icon. Rég. Anim. iii, p. 414. LaSagra, Hist. Cuba,pl. 18, fig. 4.

Hab.-Cuba. (Poey.) Two $\delta$ o specimens. Readily distinguished from all the other N. A. species by the broad, heavy yellow markings. The form of both sexes is similar to that of affinis, to which it is allied also in ornamentation, although much slighter in the latter species. The prothorax is broadly margined, laterally and posteriorly, with yellow, leaving anteriorly a large semi-circular black mark, bicoloredreddish and black-in $q$; the scutellum is yellow except narrow basal margin; the metathorax, a large mark on posterior margin of pleura and also a line over tegulæ, are also yellow; tegulæ fulvous; wings yellow, tipped with dusky; legs yellow, with ferruginous coxæ tipped beneath with yellow; posterior femora fuscous, reddish above and rather broadly yellow at base and apex; abdomen ferruginous at apex, with a yellow streak on each side of ovipositor, a broad yellow band at apex of first segment and another on the third, the second with a small lateral spot; ovipositor attaining nearly to base of scutellum. The $\delta$ has only a spot on each side of metathorax instead of a band; base of coxæ black; abdomen with three broad, continuous yellow bands. Length $\delta$ ₹, .40 inch. Parasitic upon Megachile Poeyi, Guér.

\section{Leucospis aflinis.}

Leucospis affinis, Say, Long's Second Exped.ii, p. 327, $\widehat{Q},(1824) .=$ fraterna

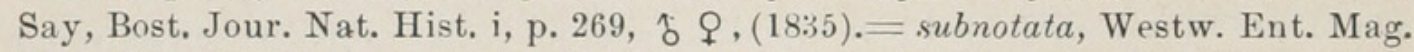
ii, p. 215. (1835); Germ. Zeits. Ent. ii, p. 250, $\hat{\delta},(1839)=$ basalis, Klug. MSS. Westw. Germ. Zeits. Ent. ii, p. 264. $\delta$ ९,(1839).= canadensis, Walk. Jour. Ent. i, p. 17, $\delta,(1860)$.

Hab.-Canada to Texas. Fifty $\delta$ o specimens examined. This common species varies greatly in size (.2.)-. 45 inch) and somewhat in markings. The vertex is more or less tinged with green or purple, 
sometimes obsoletely so; the prothorax has the lateral and posterior margins generally entirely yellow, sometimes the latter are indistinctly so, while the anterior medial spot, which is generally distinct and transverse, is sometimes reduced to a dot or entirely wanting; the yellow lateral margin of metathorax, the yellow band on apex of scutellum and the yellow stripe beneath posterior wing, are distinct in all the specimens before me, while the two yellow dots on disk of the mesothorax are generally wanting; the posterior coxæ varies from almost entirely black to entirely ferruginous, and their femora have the basal and apical spots sometimes much enlarged, while their teeth vary in number and size; the abdominal markings vary lut little, the lateral spot on second segment of $q$ is sometimes wanting and the two stripes on apex is sometimes much reduced; while in the $\delta$ the apical spot is sometimes wanting; the ovipositor of $q$ also varies slightly in length.

Var. foridana. $-\delta \uparrow$. - This has all the markings bright fiery ferruginous or reddish-yellow instead of yellowish-white; apical half of flagellum black, with the terminal joint dull ferruginous; the head is without any metallic lustre; the thoracic markings are all well-defined except the two discal marks on mesothorax, which are subobsolete; the wings are dark fuscous along costa; posterior coxæ almost entirely ferruginous, and their femora broadly reddishyellow at tips, or reddish with a discal fuscous spot, the teeth numerous and minute, except the basal one, their tibiæ orange-yellow ; first segment of abdomen ferruginous, with a narrow reddish-yellow band before apex, apical margin black; second segment immaculate; the subapical band on third segment rather narrow and regular, the two stripes on apical segment abbreviated, sometimes obsolete; the ovipositor attains the base of the abdomen. Length .45 in. Hab.-Florida. Two $q$, two $\hat{\delta}$ specimens.

\section{Leucospis azteca, n. sp.}

9.-Black, densely punctured, clothed with a short whitish sericeous pile; face tinged with green and purple, vertex strongly so ; extreme tips of antennæ fulvous, scape yellow; a narrow band near posterior margin of prothorax, narrow lateral margin of mesothorax, a broader band on apex of scntellum, sometimes a narrow line on postscutellum, apical margin of metathorax, generally interrupted, and a narrow oblique line on the flanks, all yellow; tegulæ brown or pale piceous; wings more or less dusky, aarker along costa and at apex; legs black, sericeous, posterior coxæ, their femora within and all the tibiæ within, more or less tinged with ferruginous; posterior femora with a yellow stripe on their basal half beneath, not quite reaching the base, the teeth minute, except the basal one which is broad and blunt, their tibiæ with a yellow stripe behind ; abdomen sericeous, first segment with a rather broad apical yellow band, the third segment with a narrow subapical yellow band behind which is a sublunate yellow mark enclosing a smooth shallow brownish fovea, sometimes interrupted by it, apex with a broad yellow stripe, broader beneath and divided by the ovipositor, which attains the apex of scutellum. Length .32-.40 inch.

TRANS. AMER. ENT. SOC. IV.

FEBRUARY, 1872 . 
Hab.-Mexico. Prof. Sunichrast. Three specimens. Easily recognized by the apex of abdomen being broadly yellow.

9. Leucospis dubiosa, n. sp.

१.-Differs from azteca only as follows:-Smaller; posterior femora entirely black; abdomen with a narrow yellow band at apex of first segment and another at apex of third segment; apical segment entirely black, sericeous; wings fuliginous, paler on posterior half. Length .28 inch.

Hab.-Mexico. Prof. Sumichrast. One specimen. May prove to be only a variety of azteca.

\section{Ceucospis tolleca, n. sp.}

Q.-Black, densely punctured; head tinged with dark green, clothed with a silvery sericeous pubescence; mandibles tinged with rufous; antennæ black, reddish at base of flagellum beneath, scape yellowish-white beneath ; two narrow bands on prothorax, the anterior one more or less interrupted and abbreviated, (sometimes the posterior one is obsolete), the lateral margin of mesothorax and a broad band on posterior margin, before scutellum, yellow ; scutellum immaculate, slightly tinged with green; metathorảx pale ferruginous, densely clothed with silvery pubescence; tegulæ brown; wings pale fuscous, with a central longitudinal, hy aline streak; legs black, sericeous, coxæ more or less tinged with brown; a short stripe on anterior femora at tips above, their tibiæ in front, extreme tips of intermediate femora and base of their tibiæ, small spot at tip of posterior coxæ, a broad stripe on their femora above, not reaching base, and another beneath from large tooth to base, and their tibiæ, all yellow; tarsi pale fulvous; femoral teeth minute; abdomen short, robust, slightly contracted at apex of first segment, densely and finely punctured, clothed with a very short silvery sericeous pile; first segment shining, green above, with a deep piceous excavation at base, and before the apex a smooth polished piceous band; second and third segments each with a broad apical band of sericeous pubescence, changing from silvery to pale golden-green when viewed in eertain lights; ovipositor short, porrect, not reaching to base of third segment, although the groove extends quite to base of second segment. Length .25 inch.

$\delta$-Differs only in the shape, color and sculpture of the abdomen, which is clavate, more strongly tinged with green, the second segment being much contracted at base; first segment less shining, more deeply and coarsely punctured, with no piceous band near apex, apex of abdomen clothed with a golden green pubescence, and the terminal segment very small. Length .25 inch.

Hab.-Mexico. Prof. Sumichrast. Four $q$, one $\delta$ specimens. This is our smallest species, resembling Sumichrastii more than any of its congeners ; the form is, however, not so robust and the $q$ abdomen not abruptly narrowed at base of second segment ; the yellow markings of thorax and the silvery bands of abdomen will easily distinguish this from Sumichrastii. 
The following species have not been identified :-

Leacospis Shuckardi, Westw. Ent. Mag. ii, p. 214 ; Germ. Ent. Zeits. i, 241.- " $\widehat{\delta}$-Black; head with two rounded spots between eyes; base of mandibles reddish; antennæ black, scape fulvous, extreme apex of flagellum reddish; collar with two yellow band; dise of mesothorax with two small oblong spots and a subcuneiform lateral stripe, yellow; scutellum with a broad lunate yellow band; epimera of metathorax entirely yellow; abdomen with a broad band on first segment, a narrow one on second, and a rather narrow one on third, yellow, all interrupted medially and abbreviated laterally; apex with two lunate yellow spots; ovipositor attaining to the middle of first abdominal segment; anterior and intermediate coxæ black, posterior pair black, yellow at apex ; four anterior legs yellowish-fulvous, base of femora obscure ; posterior femora piceous-black within, apex fulvous, externally yellow, with a large, rounded, inferior black spot and armed beneath with six teeth ; posterior tibiæ and tarsi fulvous, with an internal black line ; wings fuscous. Length $5 \frac{3}{4}$ lines."

Hab.-North America.

Lencospis Klugii, Westw. Germ. Zeits. Ent. i, p. 249 ; pl. 3, fig. 1.—“ $\delta$. -Opaque black; scape beneath ferruginous; narrow posterior margin of prothorax, lateral margin of mesothorax and a lunate band on apex of scutellum, yellow; basal half of abdomen black, apex yellow ; first segment with posterior margin narrowly and indistinctly yellow, and second segment with black band on apical margin; legs fusco-piceous, apex of four anterior femora yellow; posterior femora externally fuscous, inferior margin narrowly yellow, internally fulvous, armed beneath with seven black teeth; wings pale yellowish. Length $4 \frac{1}{2}$ lines."

\section{Hab.-Mexico.}

Leucospis integra, Hald. Proc. Acad. Nat. Sci. ii, p. 53.—“ $\uparrow$--Black, covered with pale yellowish pile; antennæyellowish beneath; thorax scabrous, with a spot of yellow pile posteriorly ; tegulæ yellow; wings translucent; legs yellow, except basal half of first and second pairs of femora, posterior femora black, tipped with yellow. Length 5 mill."

Hab.-Not given; probably Pennsylvania. This is possibly nothing but Chalcis ovata, Say.

Body entirely black, immaculate :

Genus SMICRA, Spinola.

Face entirely black:

Petiole as long as remainder of abdomen and nearly as long as posterior coxæ; posterior femora black or brown, generally yellowish at base; antennæ long.

1. microgaster.

Petiole shorter than remainder of abdomen and about two-thirds the length of posterior coxæ; posterior femora entirely black; the antennæ shorter.

2. canadensis.

Face with a large angular white mark 3. albifrons.

Body black, immaculate; abdomen more or less red :

Posterior femora reddish-yellow above, base and spot beneath near apex pale yellow..... 
Posterior femora obscure reddish, varied with blackish, inner side mostly reddish

. rufofemorata.

Body black, more or less marked with white or yellowish :

Markings of thorax very small and indistinct; the posterior femora with a single pale dot on upper outer middle; the abdomen entirely black

6. delumbis.

Markings of thorax small, but distinct:

Posterior femora with irregular whitish markings at apex, varied with pale brown :

Abdomen black, with two or four white spots at base.

7. torvina.

Abdomen black, with numerous lateral white spots.... 8. flavopicta.

Abdomen reddish at base and sides, with numerous pale spots..9. delira.

Posterior femora with a broad, irregular, whitish band on the apical half; the abdomen reddish at base and sides, with six white spots.................................................. 10, mendica.

Posterior femora with a broad basal margin and dot at apex above, pale yellow ; prothorax and scutellum each with two small yellowish spots; abdomen black

11. subolosoleta.

Posterior femora with a short yellowish stripe above near apex and a dot beneath; abdomen mostly yellow, petiole black.......12. Toluca.

Posterior femora margined above and at base beneath with yellowish, and armed beneath with only six teeth; apical half of the abdomen yellowish

13. mexicana.

Posterior femora pale fulvo-ferruginous, with three yellow spots at apex; abdomen pale sanguineous, with four pale yellowish spots at base

14. sanguineiventris.

Markings of thorax large, white, yellow or reddish :

Posterior femora black, margined above and at base beneath with whitish, also a white spot beneath near apex :

Scutellum black, with two large ovate white spots; posterior tibiæ with a small pale spot on outer side near base..............15. bioculata.

Scutellum yellow, except extreme base and apex; posterior tibiæ with a broad yellow annulus

16. lecta.

Posterior femora black, with basal margin beneath, a large spot at apex above, and a small spot near apex beneath, white; the posterior coxæ above and most of abdomen red; the scutellum mostly white.

19. lauta.

Posterior femora yellow, with a large, median black spot, generally confluent with a spot at apex; the scutellum almost entirely yellow; the abdomen fulvous, with a yellow subinterrupted median band.

17. ambigua.

Posterior femora yellow, with a large irregular black mark near middle and a small black spot on extreme tip; scutellum with two large yellow spots; abdomen black, with a median yellow band...16. arcana.

Posterior femora yellow, irregularly black at base and along inferior edge ; the scutellum with a large, longitudinally ovate, black, central spot

20. Nortomii.

Posterior femora yellow, with a slender, subfusiform, oblique, black stripe near apex; scutellum with a large, median, cuneiform, black spot; abdomen banded with yellow

21. coxalis. 
Posterior femora yellow, with a large central black spot, confluent with lower edge which is narrowly black to apex; scutellum with a central black stripe or basal spot:

Lower edge armed with six mostly large irregular teeth; protuberance beneath posterior wing black and yellow....

22. bracata.

Lower edge armed with twelve mostly small irregular teeth; protuberance beneath posterior wing entirely yellow.....Var. coaequalis.

Markings of body and legs bright deep orange-yellow ; posterior femora with a small black spot beneath near base; scutellum divided centrally

Body ferruginous : by a black stripe

23. encausta.

Petiole of abdomen short:

$\Lambda$ bdomen ferruginous, immaculate; head, metathorax, posterior coxæ, tibiæ and petiole of abdomen black

24. bartbarar.

Abdomen piceous-black, with two white spots ; petiole pale yellowish ; posterior coxæ ferruginous, with a large black spot..25. scutellaris.

Petiole of abdomen very long and slender :

Scutellum ferruginous, with a central black stripe, the lateral margin whitish

26. debilis.

Scutellum yellowish-ferruginous, with a large dorsal black mark

petiolata.

Body coccineous or scarlet:

Petiole of abdomen short :

Posterior femora with about five short distant teeth; four anterior legs red

28. Lanieri.

Posterior femora with numerous minute teeth; the four anterior legs black.

29. coccinea.

Petiole of abdomen very long and slender; wings fuliginous, apical third subhyaline; posterior femora immaculate, with numerous minute teeth

30. coceinata.

Body fiery yellowish-red or orange :

Wings dusky hyaline, darker towards base, the cubitus with a dark spot; scutellum with a black dot at tip; posterior coxæ with a black spot....

31. flammeola.

Wings uniformly fusco-hyaline; scutellum immaculate; posterior coxæ with a broad exterior black stripe. 32 . intermedia.

Wings clear hyaline; scutellum and metathorax with a central black stripe; posterior coxæ with a black spot. 33. ignea.

Body lemon-yellow or luteous :

Petiole of abdomen nearly as long as posterior coxæ and slender; most of head, mesothorax, scutellum, wings except apex, and abdomen except base, black

34, miranda.

Petiole of abdomen short, not more than half the length of posterior coxæ:

Posterior femora with four teeth:

Luteous; mesothorax reddish-brown, with two central luteous stripes; scutellum with a large triangular reddish-brown spot; posterior coxæ except base more or less sanguineous................35. Eubule.

Lemon-yellow; disk of mesothorax black, immaculate; the flagellum black 
Lemon-yellow; disk of mesothorax black, with three or four quadrate yellow spots; flagellum fulvous....

37. pulchra.

Lemon-yellow ; mesothorax with three black stripes; flagellum ferruginous.....

38. exornata.

Posterior femora with six teeth; body luteous; three marks on mesothorax, large spot on scutellum, and breast, black..39. compactilis.

Posterior femora with numerous small teeth :

Wings blackish, with hyaline tips ; body lemon-yellow ; mesothorax lineate with black; posterior coxæ with broad black stripe above, their femora with two black spots....

40. montezuma.

Wings hyaline or subhyaline:

Posterior coxæ yellow, bilineate with black:

Luteous; posterior femora with two brown or black stripes on outer side, the lower one near base oblique; base of metathorax with two black spots.

41. azteca.

Lemon-yellow; posterior femora with a single, short, slender, oblique, black stripe on outer side near lower edge; base of metathorax black, a central apisal black spot.

42. conjungens.

Posterior coxæ black within and a slender black stripe at base on outer side; mesothorax brown, with four yellow stripes; posterior femora yellow, with a broad central fulvous stain and a black apical spot....

43. lenta.

Posterior coxæ lemon-yellow, with broad stripe above; petiole of abdomen very short; abdomen long, subfusiform, narrowly banded with black.

44. mariae.

Posterior coxæ luteous, with a dusky stripe on inner side; scutellum with a transverse black mark near tip; pleura with a broad oblique black stripe.

45. tolteca.

Posterior coxæ lemon-yellow, with a rounded black spot on outer side: Metathorax with a transverse black spot at base...46. nigropicta. Metathorax with a central elongate black spot.......47. mirabilis.

Posterior coxæ luteous, with apical half black; scutellum immaculate; posterior femora luteous, immaculate..............48. Gumdlachii.

Posterior coxæ lemon-yellow, black at extreme tips, femora with two black spots on outer side, confluent on lower edge........49. juxta.

Posterior coxæ yellowish, immaculate:

Pale luteous; thorax with small blackish markings... 50. pallens.

Pale lemon-yellow, immaculate; abdomen coccineous on apical half.

51. delicata.

Pale lemon-yellow, immaculate; abdomen tinged with rufo-testaceous

52. immaculata.

\section{Smicra microgaster.}

Chalcis microgaster, Say, Long's Second Expedition, ii, p. 326.

Hab.-New York, Connecticut, Pennsylvania, The antennæ are long, robust, the scape more or less compressed at tip beneath; the four anterior legs more or less dull yellowish, the posterior femora not so much swollen as usual, sometimes brown and generally more or less tinged with reddish-yellow at base, the teeth are numerous and minute; 
posterior tarsi pale; petiole slender, cylindrical, nearly as long as posterior coxæ and as long as the remainder of abdomen, which is small and subglobose, polished and black. Length .15 inch.

\section{Smicra canadensis, n. sp.}

§.-Entirely black; face transversely rugose; clypeus smooth and polished, piceous; antennæ subrobust, scape cylindrical, not compressed beneath at tip; thorax densely and coarsely sculptured; apex of scutellum rounded; metathorax coarsely reticulated, with a central ridge furcate before apex; tegulæ piceous; wings hyaline, iaintly dusky at tips ; four anterior legs more or less varied with yellowish-brown; posterior femora entirely black, rather larger than in preceding species, the teeth numerous and minute; tarsi pale; abdomen entirely black, smooth and shining; petiole stout, shorter than remainder of abdomen and about two-thirds the length of posterior coxæ. Length .16 inch.

Hub.-Canada. Two specimens. Stouter than microgaster, with shorter antennæ, larger posterior femora and shorter, stouter petiole.

\section{Smicra albifrons.}

Chalcis albifrons, Walsh, Ins. Inj. Veg. Ill. p. 37, fig. 8.

Hab.-Illinois. This is the smallest species known to me, being only .08 inch long. It is easily distinguished by the large angular white mark on the face. The posterior femora have a whitish streak on the upper basal half of outer side.

\section{Smicra flebillis, $\mathrm{n}$. $\mathrm{sp}$.}

ऊ.-Black, clothed with pale pubescence; clypeus and mandibles redish; antennæ long, black, scape piceous, compressed and carinate beneath at apex ; thorax densely and confluently punctured,immaculate; scutellurn subconvex, rounded and margined at apex; metathorax coarsely reticulated; tegulæ pale brown; wings slightly dusky, subiridescent; legs yellowish-ferruginous, coxæ, troehanters and base of four anterior femora black; posterior femora brown. black, orange-yellow at base, shading into pale yellow beneath, a pale yellow spot near tip and a smaller one above it, inner side pale orange-yellow with a brown mark on middle curving to apex above, teeth numerous and minute; posterior tibiæ black with a pale yellowish spot near base; abdomen subglobose, smooth and polished, piceous, reddish at base and sides, pubescent at apex, petiole black, stout, cylindrical, nearly as long as remainder of abdomen. Length .20 inch.

Hab.-Massachusetts. Two specimens. Resembles microgaster in form, but is larger, with posterior femora maculate with yellowish, and the abdomen mostly red.

\section{Smicra rufofemorata, n. sp.}

\}.--Dull black, head rugose, mandibles tinged with reddish; antennæ as long as head and thorax, scape compressed beneath; thorax immaculate, with dense coarse punctures; metathorax coarsely reticulated, pubescent; tegulæ piceous; wings fusco-hyaline; legs ferruginous, coxæ, trochanters, four anterior femora at base and beneath, and the four posterior tibiæ, black; posterior 
femora not as large as usual, more or less stained with fuscous, the teeth very minute; posterior tarsi yellowish; abdomen small, subglobose, smooth and polished, ferruginous, dusky at apex, petiole stout, cylindrical, black, about two-thirds as long as posterior coxæ. Length .20 inch.

Hab.-Texas. (Belfrage.) Two specimens. Same form as flelilis, to which it is very closely allied, and may prove to be only a variety of it.

\section{Smicra delumbis, n. sp.}

$\delta$ Q.-Black; spot between antennæ, short line on anterior orbits, interrupted line behind eyes, and mandibles except tips yellowish-white; antennæ black, flagellum sericeous, apex sometimes pale; two whitish, approximate dots on lateral anterior margin of prothorax ; two small distant spots on disk of mesothorax, wanting in $\$$, and a dot on each side of scutellum, pale ferruginous; apex of scutellum rounded, margined, unarmed; tegulæ pale piceous; wings tinged with dusky, subiridescent; extreme base and apex of four anterior femora, base and apex of their tibiæ and within and their tarsi pale yellow ; posterior trochanters luteous in $\hat{\jmath}$, their femora ovate, with a yellow dot on upper outer middle and a spot at tip above in $\$$, teeth numerous and minute, their tibiæ with a pale yellowish spot near base and at apex, their tarsi white; abdomen small, about as large as posterior femora, subglobose, smooth and polished, black, immaculate, petiole stout, rather more than half the length of posterior coxæ. Length .15 inch.

Hab.-Massachusetts, Delaware. Two ( $\delta$ ) specimens. Much like canadensis.

\section{Smicra torvina, n. sp.}

Q.--Black, opaque; spot between antennæ, transverse spot beneath each posterior ocellus, spot on anterior orbits, narrow posterior orbits, and the large mandibles except tips, pale yellow; thorax densely rugulose; prothorax with four whitish dots on anterior margin - two on each side and two, approximate, above-and a reddish spot near each posterior angle; mesothorax with a short line on each side of middle lobe and two spots on posterior part of each lateral lobe, pale orange-yellow; scutellum with a rounded pale yellowish spot on each side, tegulæ pale yellow, fuscous posteriorly; wings hyaline; legs black, sericeous, tips of four anterior femora, their tibiæ at tips and within and all the tarsi except tips, yellowish-white; posterior coxæ entirely black; their femora black, inner side with a yellowish apical spot, outer side with a spot at base beneath, a spot at tip above and a transverse tortuous band near apex, pale yellowish, sometimes irregularly margined with brown, and interrupted into spots, femoral teeth minute; posterior tibiæ black, with a yellowish annulus at tip and another near base; abdomen subfusiform, smooth and polished, first segment with a whitish spot on each side between middle and apex, sometimes wanting and the second segment with a larger spot of same color on each side at base, sometimes the fifth segment has lateral pale spot; petiole robust, scarcely half the length of posterior coxæ. Length .15-.20 inch.

Mab-Massachusetts, Connecticut, Illinois, Texas. Ten specimens. The markings on posterior femora vary considerably. 


\section{Smiera flavopieta.}

Smiera flavopicta, Cress. Proc. Ent. Soc. Phil. iv. p. 99.

Hab.-Cuba. Very closely allied to torvina; the third, fourth and fifth abdominal segments have two yellow spots on each side, and the posterior femora are rather differently ornamented.

\section{Smicra delira, $n$. sp.}

$\widehat{\delta}$ - Black; face prolonged beneath eyes; a large subrhomboidal spot between and beneath base of antennæ, a large spot beneath eyes, and mandibles except tips white; narrow posterior orbits continued upward over the summit of the eye and then transversely to lower ocellus, a dot behind each upper ocellus and a dot on anterior orbits, ferruginous ; first joint of antennæ long, very robust, fulvous, with a black stripe at tip within; second joint elongate, about one-fourth the length of the first, fuscous; flagellum ferruginous, fuscous above. the joints very short and compact; thorax finely punctured; prothorax varied with ferruginous markings, the anterior margin with six yellowish spots; mesothorax with four yellowish spots on each side of disk; scutellum with a lateral yellowish stripe; tegulæ pale yellow, a ferruginous dot beneath; wings hyaline; legs honey-yellow, varied with pale yellow, coxæ and base of femora black; posterior femora marbled on apical half with ferruginous and yellowish-white, teeth very minute; posterior tibiæ pale yellowish at and base apex, dusky medially; tarsi pale; abdomen ovate, smooth and shining, ferruginous at base and apex, black on disk above, with a more or less distinct whitish spot on each side of the segments, large on second and on two or three apical segments; petiole short, black. Length .15 inch.

Hab.-Texas. (Belfrage.) In style of ornamentation this approaches very nearly to torvina, which is, however, larger and differently shaped, and the abdomen differently marked.

\section{Smicra mendica, n. sp.}

$\hat{\delta}$ - - Black, varied with ferruginous and whitish; a white spot between base of antennæ; sides of face, orbits, confluent with a line that curves around the posterior ocelli and terminates on occiput, and mandibles except tips, yellowish ferruginous; scape black, ferruginous laterally, (flagellum broken off); prothorax ferruginous above, with four small yellowish spots on anterior margin; mesothorax sparsely and finely punctured, black, side pieces ferruginous, a spot on each side of anterior middle, and a spot in front of tegulæ, whitish; scutellum flat, sparsely punctured, shining, narrowly margined with pale ferruginous, with a white transverse mesial band interrupted on the disk; narrow space immediately beneath wings pale ferruginous; tegulæ pale piceous; wings hyaline, iridescent; four anterior legs honey-yellow, tarsi pale, coxæ and base of femora blackish; posterior coxæ black, their extreme tips and trochanters honey-yellow ; posterior femora much swollen, ovate, outer side with basal half black, tinged beneath with brown, and with a white spot over basal tooth, apical half irregularly white, interrupted beneath and at tip with brown and by a double black spot on upper margin near apex, on inner side black, margined above with ferruginous and with a whitish spot at tip, the teeth numerous and minute; posterior tibiæ brownish behind, with a whitish spot near base and another near apex; tarsi pale yellowish ; abdomen rather larger than pos- 
terior femora, smooth and polished, short ovate, ferruginous, piceous above, two spots on middle of first segment, two on base of second segment and two on apex, white; petiole short, stout, black. Length .20 inch.

Mab.-Mexico. (Prof. Sumichrast.) One specimen. Larger than delira which it somewhat resembles, but may be readily distinguished by the posterior femora being broadly tipped with whitish.

11. Smicra subobsoleta, n. sp.

ऊ.-Black, opaque; face, broad anterior orbits not reaching summit of eyes, narrow posterior orbits, clypeus, labrum, and mandibles except tips, lemonyellow; antennæ black above, ferruginous at tips and beneath, scape yellow beneath, flagellum short, thick, with transverse joints; thorax with dense dilated punctures, a spot on each side of prothorax above, tegulæ and a spot on each side of scutellum, pale yellow; four anterior legs lemon-yellow, the coxæ, a stripe on their femora behind, and a short slender stripe on their tibiæ, black; posterior legs black; their trochanters beneath, a spot at tip of their femora above, a large spot at base, extending on upper edge nearly half way to apex, and a dot on middle of inner side, lemon-yellow; their tibiæ with a subobsolete yellowish spot near base, their tarsi pale honey-yellow, terminal joint black; femoral teeth minute; abdomen small, not larger than posterior femora, subglobose, smooth and polished, piceous, immaculate, petiole stout, about half the length of posterior coxæ. Length .20 inch.

\section{Hab.-Texas. (Belfrage.) One specimen.}

\section{Smicra Toluca, n. sp.}

Q.-Black, clothed with pale pubescence; sides of face, extending broadly half-way up orbit of eye, and narrow posterior orbits, lemon-yellow ; antennæ black, scape slender, brown, yellow beneath; thorax broad, robust, with dense dilated punctures; narrow posterior margin of prothorax, the short lateral carina on anterior margin, two oblique stripes on middle of mesothorax, converging behind, a transverse spot over tegulæ, and two oblique spots on posterior margin of scutellum, confluent on the bilobate, acutely and rather broadly margined apex, lemon-yellow; metathorax coarsely reticulated; tegulæ brown, with a yellow central dot; wings hyaline, tinged with yellowish; legs polished black, four anterior knees, stripe on their tibiæ within and their tarsi more or less, yellowish; posterior femora with a narrow interrupted stripe above and a small spot beneath towards tip on outer side and a stripe above and two spots beneath on inner side, yellowish, lower edge with eight or ten teeth, which are larger than usual; abdomen ovate, smooth and shining, yellow, banded with reddish, on first segment with piceous which is broadly dilated beneath; petiole short, stout, black. Length .28 inch.

\section{Hab.-Mexico. (Prof. Sumichrast.) One specimen.}

\section{Smicra mexicana, $n$. sp.}

q.-Black, clothed with short pale yellowish pubescence, longer and whitish on metathorax; narrow, subinterrupted orbits, scape beneath, narrow posterior margin of prothorax, spot on each posterior angle of mesothorax, and two transverse spots on scutellum yellow; antennæ black, scape slender, brown above; thorax broad, robust, densely punctured; scutellum large, subconvex, apical marginal carina interrupted medially; tegulæ piceous; wings faintly yellowish, narrowly fuscous on costa; legs shining black; tips of four anterior femora within, anterior tibiæ within, broad stripe on posterior coxæ beneath, not 
reaching base, a continuous stripe on their femora above, a short, broad stripe at base beneath, a small spot beneath near apex, transverse band on inner side near apex (which is ferruginous), and a short stripe on their tibiæ on each side near apex, yellow; posterior femora with four large blunt teeth and two small ones, sometimes obsolete, towards base; abdomen shining, black, pointed at apex, a band on second, and the following segments more or less yellow; petiole short, stout, black. Length .35 inch.

$\delta$ - - Face spotted with yellow; posterior coxæ with a short slender yellow stripe on each side near apex; abdomen smaller, the band on the second and the following segments orange-yellow; otherwise like $q$. Length .30 inch.

Hab.-Mexico. (Prof. Sumichrast.) Five $\hat{\delta} q$ specimens. An easily recognised species. Differs from Toluca by the yeliow margined posterior femora and the paucity of the teeth.

\section{Smicra sanguiniventris, n. sp.}

P.-Black, head and thorax marked as in delira; antennæ slender, blackish, fulvous beneath ; tegulæ whitish ; wings faintly dusky; four anterior legs pale honey-yellow ; posterior coxæ black, ferruginous at tips and beneath; their femora fulvo-ferruginous, with several irregular yellowish marks at tip and a spot on basal tooth; on inner side a short black line, the teeth numerous, minute and black; posterior tibiæ fulvous, with apex and spot near base, yellow ; tarsi pale; abdomen subfusiform, smooth and polished, pale coccineous, with four yellow spots near base; petiole robust, about haif the length of posterior coxæ, dull ferruginous. Length .18 inch.

Hab.-Texas. (Belfrage.) One specimen. Readily distinguished from delira, which it resembles in the ornamentation of head and thorax, by the pale sanguineous abdomen and differently colored posterior femora.

\section{Smicra bioculata, $n$, sp.}

ऊ.-Black, opaque; face, broad anterior orbits not reaching summit of eyes, narrow posterior orbits, two dots beneath lower ocellus, clypeus, labrum, and mandibles except tips, lemon-yellow; antennæ black above, ferruginous beneath, scape with a pale stripe beneath; thorax with dense dilated punctures; a large spot on each side of prothorax above, two oblique dots on disk of mesothorax, two large ovate spots on scutellum and the tegulæ, lemon-yellow; wings hyaline; four anterior legs lemon-yellow, their coxæ, trochanters and base of femora behind black, their femora honey-yellow in front; posterior legs black, upper edge of their femora, sometimes broadly interrupted about the middle, leaving only a spot at apex, and a stripe at base beneath, sometimes nearly contiguous with a spot near apex, lemon-yellow ; a yellow spot near base of tibiæ, their tarsi honey-yellow ; femoral teeth minute; abdomen small, not larger than posterior femora, subglobose, smooth and polished, piceous, shading into ferruginous at base, petiole stout, about half the length of posterior coxæ. Length .20-.23 inch.

Var. facera, $\widehat{\delta} \cdot-$ Pale markings white; posterior femora broadly margined above at base and beneath nearly to apex; abdomen entirely ferruginous. Length .18 inch.

\section{Hab.-Texas. (Belfrage.) Three specimens.}


16. Smicran lecta, n. sp.

$\checkmark$ Q.-Black; face, mouth, broad anterior orbits not reaching summit of eyes, posterior orbits dilated beneath, and scape beneath, lemon-yellow ; flagellum beneath and at tip fulvous; thorax densely punctured, pubescent; prothorax yellow above, interrupted medially and posteriorly by a black spot on each side, lateral anterior margin also yellow; mesothorax with two short, oblique, yellow lines; scutellum large, prominent, convex, lemon-yellow, basal and apical margins narrowly black, sometimes a small black spot on basal middle; tegulæ lemon-yellow; wings faintly dusky, iridescent; four anterior legs, including their coxæ, lemon-yellow, anterior femora with a black spot at base behind; posterior coxæ with a broad yellow stripe beneath; their femora with upper edge, not reaching apex, and basal half beneath, broadly lemon-yellow, also a small spot on lower edge between middle and apex, on inner side the upper edge, the extreme base and a large subapical spot, also lemon-yellow, teeth numerous and minute; posterior tibiæ yellow, black at base and apex ; tibiæ yellow; abdomen small, smooth, shining, dark ferruginous, immaculate, piceous towards apex above; petiole short, black. Length $.20-.23$ inch.

Hab.-Mexico. (Prof. Sumichrast.) Two specimens.

17. Smicra ambigua, n. sp.

ઈ.-Black, pubescent; head lemon-yellow, vertex and occiput black ; flagellum fulvous beneath and at tip, scape yellow beneath; prothorax yellow with a large black spot in front; mesothorax with two broad oblique stripes on disk and lateral margins, yellow; scutellum large, prominent, convex, yellow; a small spot on basal middle and a short band on apical margin, black; pleura with two spots beneath wings, that beneath tegulæ small; tegulæ pale yellow ; wings tinged with dusky, pale at apex; legs lemon-yellow; posterior coxæblack, yellow beneath, their femora on each side with a large irregular black spot on disk and another at apex, sometimes conflnent, the teeth numerous, minute and black; posterior tibiæ broadly black at base and apex; abdomen small, sub-globose, fulvo-ferruginous, sometimes darker on apical half, with a stain on each side of first segment and a band or two spots on base of second segment, pale yellow; petiole short, not half the length of posterior coxæ, black, more or less pale at base. Length .20-.25 inch.

Hab.-Mexico. (Prof. Sumichrast.) Five specimens. Closely allied to lecta and may prove to be a variety of that species. This seems also to approach abdominalis, Walk., which however is said to have the petiole long and the abdomen piceous.

\section{Smicra arcana, $n$. sp.}

$\delta$.-Robust, black; head yellow, large spot or vertex enclosing ocelli, occiput, clypeus, dot beneath eyes and tips of mandibles black; antennæ black, scape yellow beneath; large mark on each side of prothorax, two oblique spots an middle of mesothorax, two large spots on scutellum, postscutellum and tegulæ, yellow; thorax densely and confluently punctured; wings hyaline; four anterior legs yellow, their coxæ, trochanters and base of femora black; posterior coxæ black with a pale yellow spot beneath; their femora large, yellow on outer side, with a large irregular, submedian black band not reaching upper edge but curving to base which it attains by a narrow line, apex with a black spot, inner side blackish, with upper margin and a broad band near apex, 
yellow, teeth numerous and minute; posterior tibiæ yellow, brownish near base; abdomen shining, piceous-black, with an abbreviated yellow band at base of second segment; petiole short, stout, black. Length .20 inch.

$H a b$-Delaware. One specimen.

19. Smicra lauta, n. sp.

9.-Black; head white, lower margin of face brownish; a spot on middle of front, spot covering ocelli, confluent with occiput, and tips of mandibles black; antennæ black, seape white beneath ; thorax with rather sparse, not deep, punctures, shining; posterior margin of prothorax dilated laterally, four longitudinal stripes on mesothorax, scutellum except base and apex, and the tegulæ, white; scutellum large, rounded at tips, depressed centrally; wings tinged with dusky ; four anterior legs white; posterior coxæ black beneath, dark red above, their femora black, with a large irregular spot above at tip, a small rounded spot beneath and an elongate spot at base beneath, white, inner side reddish with two whitish spots near tip which is black, teeth numerous and small; posterior tibiæ dull ferruginous, their tarsi whitish; abdomen smooth and polished, pointed at tip, rufo-piceous; petiole very short and stout, yellowish-ferruginous. Length .25 inch.

Hab.-Mexico. (Prof. Sumichrast.) One specimen. A very handsome and distinct species.

20. Smicra Nortonii, n. sp.

ऊ.-Head lemon-yellow, space behind antennæ, vertex except a short line before each posterior ocellus, occiput, a small oblique spot beneath base of each antenna, lower margin of cheeks narrowly and tips of mandibles, black; scape black above, yellow beneath, (flagellum wanting); thorax broad, robust, with large, dense, coarse punctures; prothorax yellow; mesothorax black, with four narrow yellow stripes, the two central ones oblique, converging and abbreviated behind, almost contiguous; scutellum yellow, with a large longitudinally ovate black discal spot; metathorax black with apex yellow; pleura black, a spot beneath wings and the large prominent convex swelling behind, yellow; tegulæ pale yellow, pupilled with brown; wings yelluw-hyaline; legs lemonyellow, posterior coxæ with a broad black stripe above and beneath, not reachapex; their trochanters black; their femora large, oblong, irregularly black at base, as well as the inferior margin which has about ten irregular teeth, on inner side the base is obliquely black and with a short oblique central band abbreviated above; their tibiæ pale fuscous at the extreme base; abdomen banded alternately with black and yellow, the first segment with two blackish spots at base; petiole short, reddish-brown, yellow above. Length .35 inch.

Hab.-District of Columbia. (Coll. Mr. E. Norton.) One specimen. This fine species, which at first sight closely resembles the three following, may be distinguished at once by the yellow posterior femora being black only at base on outer side.

\section{Smiera coxalis, n. sp.}

S.-Black, profusely marked with lemon-yellow; face transversely rugose, lemon-yellow, with two approximate blackish marks above clypeus; space behind antennæ covering vertex and occiput black; seape lemon-yellow beneath; 
prothorax lemon-yellow, a large transverse spot on anterior middle and a spot on each posterior corner, black; mesothorax densely and coarsely punctured, black, with four yellow stripes, those on disk oblique, converging and abbreviated behind; scutellum yellow, with a large, broad cuneiform, discal black mark; metathorax yellow, black on basal margin ; pleura black, with a slender yellow line on anterior margin, the prominent convex swelling beneath.posterior wings entirely yellow; tegulæ pale luteous; wings yellowish-hyaline; legs lemon-yellow; posterior coxæ very long, attenuate at tips, black beneath, with two black stripes above, the outer one abbreviated at base; their femora with an oblique black stripe on each side near base, and the extreme tips black especially on inner side; their tibiæ dusky at base; abdomen subcompressed, smooth and shining, subpubescent, black, first segment except apical margin, and broad band at base of second and third segments, yellow; petiole short, black. Length .30 inch.

Hab.-Delaware. One specimen. Easily recognised by the conspicuous oblique black stripe on posterior femora near base.

\section{Smicra bracata.}

Chalcis bracata, Sanborn, Rep. Sec. Mass. Bd. Agric. Jan. 1863, p. 172, fig. 46.

Hab.-Conn., Penn., D. C. Three specimens. Closely allied to Nortonï, differing principally as follows:- Scutellum with a large, longitudinal ovate black spot; metathorax black, except spines which are yellow; protuberance beneath posterior wings black and yellow; posterior coxæ entirely black except a yellow spot at base of outer side; posterior femora with a large discal black spot on outer side and black on inner side with a yellow spot at base and another near apex; lower edge with four large and two to four very small teeth; posterior tibiæ black at base. Length .28-.35 inch.

Var. COAQUALIS. - $\delta$.-Differs only by the femora having twelve mostly small irregular teeth, entirely different from those of bracata, and by the protuberance beneath posterior wing being entirely yellow. Length .23-.28 inch.

Hab. - Massachusetts, Delaware. Two specimens.

This may be the nigricornis, of Fabr., or the maculata, of Fabr., although of the latter Walker (Entomologist, p. 218,) says "scutellum apice bicornutum ; trochanteres flavi," while in bracata the scutellum is broadly rounded at apex and unarmed, and the trochanters are black. In other respects there appears to be nothing to separate them.

\section{Smicra encausta, n. sp.}

S.-Robust, black; head orange-yellow, middle of the front behind antennæ confluent with a transverse mark on vertex enclosing ocelli, which is confluent with posterior margin of head, black; antennæ short, robust, black, scape with a yellow stripe beneath; thorax short, broad, with rather large dilated punctures; prothorax orange-yellow with a large black mark on anterior middle; 
two oblique marks on disk of mesothorax, narrow lateral margin, and the scutellum except a slender dorsal depressed stripe, also orange-yellow; pleura entirely black; tegulæ pale yellow, brown posteriorly; wings dusky, pale at apex; legs orange-yellow, four anterior coxæ, trochanters and extreme base of their femora, black; posterior coxæ short, black, a large spot, furcate anterior$1 y$, beneath at tip and a smaller one near base within, yellow; their trochanters black; their femora large, almost circular, with a small black spot on lower middle of outer side and another at extreme tip on both sides, teeth numerous, minute and black; their tibiæ blackish, with a narrow orange-yellow band near base and apex; their tarsi yellowish; abdomen as large as posterior femora, compressed, shining, black, a spot on each side of first segment at base and a narrow band at base of second segment, orange-yellow; petiole short, stout, black. Length .20 inch.

Hab.-Colorado. One specimen. This truly lovely species may be easily recognised by the beautiful bright orange markings in contrast with the deep black color of the body, and by the large nearly circular posterior femora being almost entirely orange-yellow.

\section{Smicra barbara, n. sp.}

\}.-Same form and sculpture as rufofemorata; ferruginous; head fuscous, sides of face ferruginous; antennæ slender, black, scape sometimes tinged with reddish; pleura, metathorax and tegulæ more or less black; wings fusco-hyaline; coxæ, except sometimes posterior pair above, base of anterior femora, and four posterior tibiæ, black; posterior femora almost sanguineous, immaculate, with minute black teeth; posterior tarsi fulvous; abdomen as in rufofemorata; petiole shorter, fuscous. Length .20-.25 inch.
Hab._Texas. (Belfrage.) Three specimens.

\section{Smiera scutellaris.}

Smiera scutellaris, Cress. Proc. Ent. Soc. Phil. iv, p. 98. Jan. 1865.

Hab.-Cuba. (Coll. Dr. Gundlach.) One specimen. This is dull ferruginous, with antennæ, most of pleura, large spot on posterior coxæ, part of femora and tibiæ and most of abdomen black; sides of face, whole of scutellum, tips of posterior coxæ, spots on their femora and tibiæ and a spot on each side of abdomen above, pale yellowish. Length .23 inch.

\section{Smicra debilis.}

Chalcis debilis, Say, Bost. Jour. Nat. Hist. i, p. 271.

Hab.-Delaware, "Indiana," Illinois. This is a small slender species, of a ferruginous color, varied with pale and black markings; the petiole of abdomen is very long and slender. Length .15 inch.

\section{Smicra periolata.}

Smiera petiolata, Cress. Proc. Ent. Soe. Phil. iv, p. 97.

Hab.-Cuba. (Coll. Dr. Gundlach.) One specimen. Closely allied to debilis, Say. The petiole is twice the length of the remainder of abdomen, and very slender. Length .15 inch. 


\section{Smicra Lanieri.}

Chalcis Lanieri, Guér. Icon. Rég. Anim. iii, p. 412, pl. 67, fig. 4.

Hab.-Cuba. Two $\delta \subsetneq$ specimens. A large bright scarlet or coccineous species, with head above and behind, antennæ, most of mesothorax, a broad stripe on posterior coxæ above, a single spot or streak near base of their tibiæ, black; wings uniformily dark fuscous; the femoral teeth five in number, distant and irregular; metathoracic spines prominent; abdomen immaculate, petiole short and stout. Length .35 inch.

\section{Smicra coccinea.}

Smiera coccinea, Cress. Proc. Ent. Soc. Phil. iv, p. 91.

Hab.-Cuba. (Coll. Dr. Gundlach.) One specimen. This is allied to Lanieri, but is at once distinguished by the thorax, posterior coxæ, femora and tibiæ being entirely coccineous, and the four anterior legs black. Length .25 inch.

30 Smicra coccinata, $n$. sp.

$\delta$-Coccineous; head yellowish, vertex, occiput and two spots on face, black ; antennæ black, scape compressed, with a yellowish carina beneath near apex; thorax coarsely transversely wrinkled, a spot on each side of prothorax above, two short broad stripes on disk of mesothorax, a spot on each side over wings and two rounded spots on base of scutellum, black; scutellum coarsely transversely wrinkled, convex, apex with two prominent compressed rounded processes; metathorax coarsely reticulated; tegulæ dull luteous; wings blackish fuscous, apical third subhyaline; legs bright coccineous, two anterior pairs paler, with tibiæ and tarsi tinged with yellowish; posterior trochanters and row of numerous minute femoral teeth black; tarsi yellow; abdomen small, globose, smooth and polished, petiole as long as remainder of abdomen, slender, whitish. Length .27 inch.

Hab.-Mexico. (Prof. Sumichrast.) One specimen.

31. Smiera flammeola, n. sp.

$\delta$ Q.-Fiery reddish-yellow; head yellow, vertex and occiput tinged with reddish-yellow; antennæ black, scape yellow beneath; prothorax strongly tinged with yellow; mesothorax transversely rugulose, clothed with short erect black pubescence, the anterior, posterior and dorsal sutures and a slender black median stripe, sometimes abbreviated, black; scutellum with erect black pubescence, and a central dusky stripe, apex rounded, margined, $\hat{\delta}$ with a central black dot at tip; mesothorax coarsely reticulated, tinged with yellowish; base sometimes narrowly black; pleura tinged with yellow and with two black oblique stripes;on each side, sometimes reduced to spots near base of four anterior coxæ; tegulæ pale yellowish; wings dusky hyaline, pale at tips, a slight dusky cloud beneath tip of humerus and a small blackish spot covering the cubitus; four anterior legs lemon-yellow; posterior legs fiery orange-yellow, smooth and polished; the coxæ more or less black within, and in $\hat{\delta}$ a black dot on outer side near base, in $\mathcal{f}$ this is indicated merely by a dusky stain; trochanters of $\delta$ black; femora of $q$ with a dusky stain on outer middle, the 
teeth numerous, small and black; tarsi pale orange-yellow; abdomen long, fusiform, acuminate at tip in $q$, short, ovate in $\delta$; petiole short, stout. Length $.26-.36$ inch.
Hab.-Mexico.
(Prof. Sumichrast.)
Five $\hat{\jmath} q$ specimens.

\section{Smiera intermedia.}

Smiera intermedia, Cress. Proc. Ent. Soc. Phil. iv, p. 92.

Hab.-Cuba. (Coll. Dr. Gundlach.) One specimen. Yellowishferruginous; abdomen scarlet; vertex, occiput, cheeks, antennæ, tegulæ, four anterior legs, posterior coxæ above and their tibiæ and tarsi, black; wings fusco-hyaline. Length .25 inch.

\section{Smicra ignea.}

Smiera ignea, Cress. Proc. Ent. Soc. Phil. iv, p. 92.

Hab.-Texas; Cuba. Reddish-orange ; flagellum, central stripe on mesothorax, a small spot on each side of it, as well as the anterior and posterior margins, a central spot on posterior coxæ above and the extreme tip of abdomen, black; wings hyaline; abdomen elongate, acuminate and pointed; petiole short, pale yellow. Length .25 inch.

\section{Smicra miranda, n. sp.}

S.-Pale lemon-yellow; head black, a short line on anterior orbits, cheeks, and mandibles yellow; antennæ black, scape dull yellowish, compressed and carinate beneath near apex; mesothorax transversely wrinkled, black, as well as scutellum except apex, which is bituberculate as in coccinata; tegulæ pale luteous; wings blackish, apical third hyaline; extreme tips of posterior coxæ, their trochanters, the numerous, minute femoral teeth, and tips of their tibiæ black; abdomen black, smooth and polished, subglobose, yellowish at base; petiole long, slender, nearly as long as posterior coxæ, lemon-yellow. Length .30 ineh.

Hab.-Mexico. (Prof. Sumichrast.) One specimen. This beautiful species is shaped and seulptured precisely like coccinata, and may prove to be the $\hat{\delta}$ of Lamyrus, Walker.

\section{Smicra Eabule.}

Smiera Eubule, Poey MS.-Cress. Proc. Fnt. Soc. Phil. iv, p. 93.

Hab.-Cuba. Four specimens. Luteous; vertex, antennæ, spot on each side of prothorax, most of mesothorax, large triangular spot on scutellum, apical half of posterior coxæ and spots on their femora, dull ferruginous; scutellum and metathorax each with two acute spines; posterior femora armed beneath with four large teeth, the basal one very stout; wings subhyaline; sometimes the prothorax above, the mesothorax and scutellum are entirely brownish and the posterior coxæ rufous except extreme base. Length .35 inch. This species destroys the larvæ of Callidiyas Eubule.

\section{Smicra dorsata, n. sp.}

‥-Bright lemon-yellow; space behind antennæ, vertex, occiput, scape behind, flagellum, spot on disk of prothorax, mesothorax except broad lateral mar-

FEBRUARY, 1872. 
gin, large triangular spot at base of scutellum, metathorax except large mark beneath posterior wing, and a large irregular, crenulated depression on pleura, black; thorax with dense coarse punctures, clothed with a rather long pale pubescence; wings hyaline; tips of posterior coxæ, their trochanters, three spots on outer side of their femora-one on middle of upper margin, one at tip and a larger one on middle of lower margin, extending to inner side-and base of their tibiæ, black; femoral teeth four in number, the two middle ones long, acute, black, the others blunt and tipped with black; tips of tarsi dusky; abdomen small, subcompressed, smooth and polished, stained with ferruginous at base, the segments above banded with black; petiole bright yellow, slender, more than half the length of posterior coxæ. Length .25 inch.

Hab.-Texas. (Belfrage.) This may prove to be only a variety of pulchra.

\section{Smiera pullehra.}

Smiera pulchra, Cress. Proc. Ent. Soc. Phil. iv, p. 94.

Hab.-Mexico; Cuba. Five specimens. This species is lemon-yellow ; antennæ brown-ferruginous; spot on vertex, occiput, disk of prothorax, large mark on mesothorax enclosing three or four yellow spots, most of pleura and metathorax, tips of posterior coxæ, three spots on their femora, base of their tibiæ and bands on disk of abdomen, black; wings subhyaline; scutellum and metathorax each with two stout acute teeth; posterior femora armed beneath with four large acute black teeth, the two middle ones the longest and directed backwards. A specimen from Mexico has a broad central black stripe on scutellum. Length .20-.25 inch.

38. Smicra exornata, n. sp.

$\hat{\delta}$-Lemon-yellow; back part of head, three more or less dilated stripes on mesothorax, a transverse band in front, another on posterior margin, a slender central stripe on scutellum, generally ending in a broad triangular mark at apex, and an oblique line on pleura, black; antennæ blackish above, fulvous beneath, scape yellow ; scutellum bilobate behind ; wings hyaline; tips of posterior coxæ, their trochanters, a short stripe on upper edge of their femora, a spot at tips, a round spot on lower edge between middle and apex, the four long acute oblique teeth, three spots on inner side, and extreme base and apex of their tibiæ, black; their femora more elongate than usual, not so much swollen; abdomen banded with black above; petiole short, yellow. Length .22-.25 inch.

\section{Hab.-Mexico. (Prof. Sumichrast.) Four specimens.}

\section{Smicra compactilis, n. sp.}

P.-Dull luteous; depressed space behind antennæ, back of head, a large mark un disk of mesothorax, a narrow longitudinal mark on each side, none of which extend to posterior margin, a broad, transverse mark on disk of scutellum and most of the pleura, black; antennæ — ; thorax broad, densely coarsely punctured; scutellum large, bituberculate behind; wings dusky, especially along costa ; legs entirely luteous, posterior femora large, much swollen, armed beneath with four large teeth tipped with black; abdomen pale yellow at base 
and apex, varied with dusky on dorsal middle; petiole short, stout. Length .30 inch.
Hab.-Mexico.
(Prof. Sumichrast.)
One specimen.

\section{Smicra montezuma, $n$. sp.}

S.-Lemon-yellow; spot on middle of front, a band on back of head, antennæ, except scape beneath, spot on anterior middle of prothorax, a large mark on anterior middle of mesothorax enclosing a yellow spot, a stripe on each side connected behind by a narrow sutural line, a dot on basal middle of scutellum and a sutural line on pleura, black; scutellum rounded and margined at apex; metathorax with a prominent subacute lateral spine; wings blackish, apical third subhyaline; extreme tips of posterior coxæ, a broad line above not reaching base, their trochanters, a spot on tips of their femora, a spot near lower edge between base and apex, the minute teeth and extreme base of their tibiæ, black; abdomen pale fulvous, with base and band at base of second segment yellow; petiole short, stout. Length 30 inch.

Hab.-Mexico. (Prof. Sumichrast.) Two specimens.

\section{Smicra azteca, n. sp.}

S.-Luteous-yellow, head and thorax beneath lemon-yellow; the excavation behind antennæ, dot on each posterior ocellus and back of head, black; flagellum ferruginous, scape yellow; a dot on anterior middle of prothorax, a spot or short line on each side above, sometimes wanting, four lines on mesothorax, the central two converging behind where they unite and reach the basal margin in one line, a central stripe on scutellum and sometimes the sutures of pleura, black; thorax densely punctured; scutellum rounded and margined at apex; metathorax coarsely reticulated; wings yellow-hyaline, paler at tips; four anterior legs entirely lemon-yellow; posterior pair luteous, their coxæ with two black stripes the upper one generally much broader and longer than the outer; posterior femora large, both sides with a stripe above and an oblique stripe towards base beneath, black, sometimes those on outside are pale brown and sometimes nearly obsolete; the teeth numerous, minute and black; posterior tibiæ brown at base; abdomen yellow, bands with fuscous or dull fulvous; petiole short, stout, with a lateral black spot on stripe. Length .30-.40 inch.

Hab.-Mexico. (Prof. Sumichrast.) Five specimens.

\section{Smicra conjungens.}

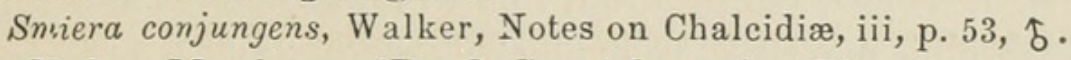

Hab.-Mexico. (Prof. Sumichrast.) Three $\delta$ specimens. This fine species is yellow, with head behind, space behind antennæ, two dots including the two posterior ocelli, a band on prothorax in front, a short streak on each side, three stripes on mesothorax, the middle one very broad and dilated in front, all connected on hind border, a central stripe on scutellum, basal margin of metathorax, a dilated spot on apical middle, a short oblique line on each side within lateral swelling, and two oblique stripes on pleura, all black; scutellum rounded at apex and unarmed; wings yellow-hyaline, faintly dusky at tips; posterior coxæ with a broad black stripe within and a very slender one on outer side, sometimes indistinct; posterior femora on inner side with two black stripes, the upper one emitting two black, bands, one on middle 
angular, and the other at tip, outer side with lower edge and a short oblique streak below the middle, black, the teeth small, irregular, tipped with black; posterior tibiæ with a blackish streak behind, not reaching apex; abdomen with broad black bands, first segment with two large black spots at base; petiole about two-thirds the length of posterior coxæ, black at tip. Length .35 inch. This is a near ally to azteca, but the posterior legs are differently marked.

43. Smicra lenta, n. sp.

$\widehat{\delta}$.-Head lemon-yellow, vertex tinged with fulvous, as well as back of head, the posterior margin of which is black; antennæ fulvous, paler at tips, scape yellow beneath; prothorax fulvous, varied with yellow, a black spot on each side beneath lateral angle; mesothorax brown, with four yellow lines, two on each side, approximate, and all connected with the yellow posterior margin; scutellum yellow, with a large rounded, central, reddish-brown spot, the apex produced, subbilobate, blackish; metathorax coarsely reticulated, black, with a broad basal yellow band; pleura black, with two yellow spots beneath tegulæ, which is yellow, pupilled with brown; wings yellow-hyaline, apex clear hyaline; legs lemon-yellow; posterior coxæ fulvous above, black within, with a short slender blackish line on outer side, distinct at base and gradually fading towards apex; posterior femora lemon-yellow, with a broad median fulvous band, irregular in outline and dilated on upper edge, a black spot on extreme tips, inner side blackish, two spots near apex and lower margin yellow, the teeth numerous, small, black; posterior tibiæ yellow, varied with fulvous; abdomen pale yellow, varied with fulvous before apex; petiole very short, stout, yellow. Length .22 inch.

Hab.-Mexico. (Prof. Sumichrast.) One specimen.

\section{Snicra mariae.}

Chalcis maria, Riley, Fourth Annual Report, Nox. Ins. Mo.p. 109, fig. 39. $\delta$ ㅇ. Hab.-N. Y., D. C., Ky., La. Eight $\delta$ ospecimens examined. This pretty little species has been bred from the cocoons of Attacus Polyphemus and Promethea. It may be recognised by the following characters :-Lemon-yellow; head with an arcuate black mark behind antennæ, connected with a short longitudinal line to lower ocellus and then to back of head which is margined with black; antennæ black or brown, seape yellow beneath; a spot on anterior middle of prothorax, three stripes on mesothorax, connected before and behind by the sutural line, a spot on each side over tegulæ, a central stripe on scutellum, basal and lateral margins of metathorax, a spot on apical middle and two oblique stripes on each side of pleura, all black; mesothorax with the central black line depressed and transversely striated; wings hyaline; a broad stripe on outer side of posterior coxæ, their extreme tips, their trochanters, the minutely dentate edge of their femora and six narrow bands on abdomen, black; petiole very short in $q$, longer in $\hat{\delta}$, tipped with black; abdomen of $q$ long, fusiform, acuminate at apex, of $\hat{\delta}$ short, ovate. Length .15-.25 inch. 


\section{Smicra tolteca, n. sp.}

Q.-Dull luteous, slightly tinged with orange; excavation behind antennæ, and posterior margin of head, black; flagellum blackish, fulvous at tips, scape yellow; mesothorax tinged with pale fulvous, with a sutural line each side, a short bidentate band in front, an angular spot on disk (connected with the bidentate band by a pale fulvous line), sutural line at base, a transverse spot near apex of scutellum, and most of pleura, black; apex of scutellum broadly, acutely margined, slightly emarginate at middle; metathorax coarsely reticulate, with a short black line between it and the large lateral swelling; wings yellowish-hyaline; legs luteous-yellow, posterior pair darker, their coxæ with a dusky stripe within and a faint fulvous stain on outer side; posterior femora varied with fuscous within, the teeth numerous, small and black; their tibiæ dusky at base; abdomen elongate, fusiform, acuminate at tip, tinged with fulvous, base of first segment, and band at base of second, yellowish; petiole short, yellowish. Length .30 inch.

Hab.-Mexico. (Prof. Sumichrast.) One specimen. In some specimens the mesothorax will doubtless be ornamented as in montezuma.

\section{Smicra nigropictat.}

Smiera nigropicta, Cress. Proc. Ent. Soc. Phil. iv, p. 95.

Hab.-Cuba. Ten $\delta$ opecimens. Lemon-yellow; antennæ, anterior and posterior margins of, and three longitudinal marks on mesothorax, anterior suture of pleura, spot on scutellum, a transverse black mark at base of metathorax, large spot on posterior coxæ, tips of their tibiæ, and dorsal bands on the abdomen, black; wings hyaline; femoral teeth numerous, small and black; scutellum unarmed, Length .20.30 inch.

\section{Smicra mirabilis, n. sp.}

ऊ.-Lemon-yellow ; spot between ocelli, posterior margin of oceiput, antennæ above, spot on middle of prothorax, three stripes on mesothorax - the central one confluent with a transverse band on anterior margin and also with a band dilated laterally, before scutellum - an elongate euneiform mark on disk of scutellum, a large elongate quadrate spot on middle of metathorax, a mark beneath anterior coxæ, spot on each side of pleura, and a large spot on posterior coxæ above, all black; thorax with large dense punctures and with sparse, erect black pubescence; wings hyaline; a spot on extreme tips of posterior femora covering also base of their tibiæ, pale fuscous; femoral teeth numerous and minute; abdomen small, not larger than posterior femora, subcompressed, honey-yellow, second and following segments each with a transverse dorsal black spot; petiole short, lemon-yellow. Length .22 inch.

Hab.-Georgia (Blake); Texas (Belfrage). Four $\hat{\delta}$ specimens. Closely allied to nigropicta, from which it may be distinguished by the black mark on metathorax being longitudinal instead of transverse, as in that species. 


\section{Smicra Gundlachii.}

Smiera Gundlachii, Cress. Proc. Ent. Soc. Phil. iv, p. 93.

Hab.-Cuba. (Coll. Dr. Gundlach.) One specimen. This fine large species is luteous-yellow ; the antennæ except scape, spot on vertex, apical half or two-thirds of posterior coxæ and their tibiæ except base, black; wings subhyaline, costa fuscous; scutellum immaculate, with an obtuse tubercle on the disk and two subacute flattened teeth on the carinate posterior margin; femoral teeth numerous and small; abdominal segments with their margins pale ferruginous, the third segment having a large blackish spot above near tip ; petiole nearly as long as remainder of abdomen. Length .35 inch.

\section{Smicra juxta, n. sp.}

9.-Head lemon-yellow; excavation behind antennæ and head behind, black; antennæ fulvous, blackish above, yellow beneath; prothorax lemonyellow, with a spot on anterior middle, and one on each side, black; mesothorax black, with two oblique stripes on disk and lateral margin rather broadly yellow; scutellum lemon-yellow, with a large transverse black spot, connected to base by a slender black line, apex rounded, unarmed; metathorax with basal and lateral margin rather broadly black; sutures of pleura broadly black; tegulæ dusky; wings hyaline; legs lemon-yellow ; tips of posterior coxæ, their trochanters, a large spot on outer disk of their femora, continued beneath and within, and along inferior dentate margin to apex ending there in a spot on both sides, black; femoral teeth numerous and minute; posterior tibiæ black at extreme base; abdomen yellow, banded with black and fulvous, base of first segment with a longitudinal black stripe; petiole about half the length of posterior coxæ, black. Length .23 inch.

Hab.-Mexico. (Prof. Sumichrast.) Two specimens.

\section{Smicra pallens.}

Smiera pallens, Cress. Proc. Ent. Soc. Phil. iv, p. 96.

Hab.-Cuba. Four specimens. Pale yellow; flagellum, a central stripe and spot on each side of mesothorax (sometimes indistinct) as well as anterior and posterior margins, spot on scutellum, tip of metathorax and stain on tip of abdomen, black or dusky; legs immaculate; femoral teeth numerous, minute and dusky; wings hyaline ; scutellum unarmed. Length .10-.12 inch.

\section{Smiera delicata, n. sp.}

9.--Pale yellow, more or less tinged with honey yellow; antennæ pale ferruginous, flagellum fuscous above; thorax imperceptibly punctured, almost smooth; wings hyaline; a honey-yellow spot on extreme tips of posterior femora, also covering base of their tibiæ; femoral teeth numerous, very minute, and black; abdomen ovate, subcompressed at tip, pale coccineous, pale yellowish at base; petiole short, pale yellow. Length .15 inch.

Hab.-Texas: (Belfrage.) Two specimens. Allied to immaculata which, however, is more uniformly pale yellow except abdomen, with the petiole much longer and slender. 


\section{Smiera immaculata.}

Smiera immaculata, Cress. Proc. Ent. Soc. Phil. iv, p. 97.

Hab.-Cuba. Two specimens. Entirely pale yellowish; antennæ slightly dusky at tips; wings hyaline ; femoral teeth numerous, minute and dusky; postorior tarsi blackish at tips; abdomen tinged with fulvous; petiole as long as the remainder of abdomen. Length .10 inch.

The following species have not been identified :-

Smicra nigrifex, Sulzer. Walk. Ent. Mag. ii, p. 22.—“ $\$$.-Black; head with two spots between eyes; metathoracic scutellum bispinose at apex; tegulæ yellow; legs black; four anterior femora yellow at tips; posterior femora yellow, base above and apex black, armed with thirteen black teeth; four anterior tibiæ fuscous; posterior tibiæ yellow at tips; their tarsi fulvous, with fuscous tips ; wings dusky. Leugth 3 lines."

Hab.-Europe. Said to occur also in North America, with characters slightly modified.

Smicra side, Walker, Ann. Soc. Ent. Fr. 2 sér. i, p. 145.-“ @.-Black; spots on face and posterior orbits yellow; antennæ piceous; thorax with ferruginous spots ; petiole tolerably long; abdomen fusiform, smooth, shining, apex attenuate and acuminate, with ferruginous and yellow bands, base ferruginous, apex black; legs fulvous; coxæ black; tips of tarsi fuscous; four anterior femora piceous, tips fulvous; base of tibiæ fuscous, tips yellow; posterior femora black, base and apex varied with fulvous anà yellow; their tibiæ with black bands ; wings fuscous. Length $4 \frac{1}{2}$ mill."

Hab.-Florida. This seems to approach deliva.

Smicra pompiloides, Walker, Notes on Chalcidiæ, iii, p. 53, 1871.“ $\widehat{\delta}$.-Black; antennæ red beneath; petiole longitudinally furrowed, short; abdomen red, fusiform, as long as thorax; hind femora with a large fusiform yellow spot on outer side and on inner side a very broad yellow stripe, much narrowed towards the tips; a slender red stripe beneath along the minute black teeth ; wings cinereous, brown towards base. Length $3 \frac{1}{2}$ lines."

Hab.-Mexico.

Smicra tenebrosa, Walker, Jour. Ent. i, p. 181.-“ $\lesssim .-B l a c k$; orbits yellow, broad on face and interrupted on each side of vertex; thorax with a yellow spot on each side in front and another on each side of scutellum, which is unarmed; petiole very short ; legs yellow ; hind coxæ black, very long; hınd femora with many minute teeth, with an angular black band which traverses the disk on each side and is connected on the inner side with an apical black spot; hind tibiæ black at base and tips ; wings blackish, paler at base and along hind border. Length $2 \frac{1}{2}$ lines."

Hab.-Orizaba, Mexico.

Smiera divisa, Walker, Jour. Entom. i, p. 178.- " $\jmath$ $q .-$ Black; head with a yellow spot on each side of the front; thorax with a yellow curved band in front; scutellum unarmed, with a yellow hind border; petiole yellow, long, slender, nearly as long as hind coxæ in $\delta$; anterior tibiæ of $\delta$ yellow beneath; hind coxæ very long; hind femora with one large and several small teeth, and 
with two yellow stripes on outer side in $\hat{\delta}$, and one in $\mathcal{q}$; hind tibiæ with a yellow spot; wings cinereous, with a lurid tinge along costa. Length $3-3 \frac{1}{2}$ lines."

Hab.-Orizaba, Mexico.

Smicra dimidiata. Sichel (Conura), Ann. Soc. Ent. Fr. 4 sér. v, p. 390."Q. Black, abdomen entirely yellow ; antennæ blackish, yellowish beneath; scutellum emarginate at apex, bilobate; legs black, knees and tarsi yellow; posterior femora with five large teeth, and a large golden spot on outer middle; wings hyaline, dusky at base. Length 8 mill."

Hab.-Orizaba, Mexico.

Smicra erythrina, Walker, Jour. Ent. i, p. 179.—“ ㅇ.--Red; head yellowish in front, with a black mark behind; antennæ black, scape red; prethorax with a black sutural line between it and mesothorax; scutum of the latter with a black longitudinal line; scutellum unarmed; pectus mostly black; petiole short; abdominal segments with piceous bands on fore border; hind coxæ with black stripe on each side; hind femora with black streak and lower black stripe on inner side, armed with many minute teeth; wings cinereous. Length $3 \frac{1}{2}$ lines."

Hab.-Orizaba, Mexico. This seems allied to flammeola.

Smicra Fidius, Walker, Ann. Mag. Nat. Hist. 2 ser. v, p. 127.- “ + Red, front and under side yellow ; antennæ black, piceous beneath, scape yellow, black at tip; sides of thorax marked with yellow ; breast mostly black, a black line passes along the back of scutum of mesothorax; metathorax black; petiole short; abdomen black towards apex ; fore and middle legs bright yellow; hind coxæ yellow, tinged with red above and each having a black spot on outside; hind thighs red, their tibiæ yellow towards base which is black, having a black band across the middle and reddish at tips; hind tarsi yellow, tips piceous ; wings hyaline. Length $2 \frac{1}{2}$ lines."

Hab.-West Indies.

Smicra Pratinas, Walker, Ann. Mag. Nat. Hist. 2 ser. v, p. 130.-“ ‘-Bright red; crown of head black, a spot of same color along lower edge of eye; fore chest with a large black spot on its back and a smaller one on each side; a small black spot on each of the epimera of middle chest; petiole long; abdomen smooth, shining, short; antennæ black, red at base, joints 10-14 yellow ; hips and thighs red, latter tinged with black; shanks black, with yellow tips, tarsi yellow; hind legs red, coxæ black towards tip and that generally on upper side; hind tibiæ dark red, black at base and towards tips; wings dark brown. Length 2 lines."

\section{Hab.-West Indies.}

Smiera Ampyx, Walker, Ann. Mag. Nat. Hist. 2 ser. v, p. 129.- " $q .-$ Tawny; mouth yellow; petiole as long as abdomen which is elliptical; fore and middle legs yellow ; wings hyaline. Length $1 \frac{1}{4}$ line."

Hab.-West Indies.

Smicra fulvescens, Walker, Ent. Mag. ii, p. 25.-“ $\$$ $\uparrow$.-Ferruginous, paler beneath; antennæ fuscous, fulvous beneath; petiole slender, half the length of abdomen, shorter in $\$$; abdomen ferruginous, banded with fuscous above; legs yellowish; posterior femora with fourteen black teeth; posterior 
tibiæ fuscous beneath; wings hyaline; $\delta$ abdomen sometimes fuscous, banded with fulvous at base. Length $2 \frac{1}{2}$ lines."

Hab.-St. Vincent's Island, West Indies.

Smicra transitiva, Walker, Trans. Ent. Soc. Lond. 3 ser. i, p. 371.—“ " -Luteous; head black about the ocelli; thorax with a dilated black line; scutellum with two luteous spots and a hindward transverse luteous line; seutellum bidentate; metathorax black; petiole tawny, nearly half the length of abdomen; abdomen black, acutely conical, tawny at base; hind coxæ black towards tips; hind femora with three black spots, armed with four large black teeth ; wings dark cinereous. Length 3 lines."

Hab.-East Florida. This seems allied to pulchra, Cress., from Cuba and Mexico.

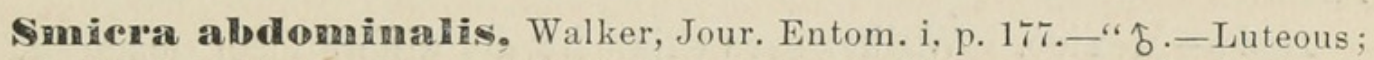
head black behind; antennæ black, tips and scape luteous; prothorax black along fore border; disks of scutum and parapsides black; scutellum unarmed, black along fore and hind border; paraptera and metathorax black; petiole long, black; abdomen piceous above, with a yellow middle band; hind coxæ black above; hind femora minutely dentate, with a black spot on each disk and with black tips; wings brownish, cinereous towards tips. Length $2 \frac{1}{2}$ lines.

Hab.-Orizaba, Mexico. Seems closely allied to ambigua.

Smicra subpunctatan, Walker, Ent. Mag. ii, p. 25.-“ $\delta$ \&.-Yellow ; head beneath with a black band; antennæ fuscous, fulvous beneath; mesothoracic scutum black anteriorly, with a central black stripe; parapsides and paraptera spotted with black; the spots between scutum and scutellum connected; scutellum with a black spot; pectus with two black spots; metathoracic scutellum with a black band; petiole half the length of abdomen; abdomen fulvous, with five dorsal black spots and apex black, first segment yellow; legs yellow; posterior coxæ with black spots; posterior femora with base beneath and apex black, armed with fourteen black teeth; posterior tibiæ at base, apex and beneath fuscous; wings hyaline; $\hat{\delta}$ abdomen sometimes fulvous, banded with fuscous. Length $2 \frac{1}{2}$ lines."

Hab._St. Vincent's Island, West Indies.

Smiera maculata, Fabr. (Chalcis) Ent. Syst. ii, p. 198. Walk. Entomologist, p. 217.

Hab._- Cayenne." (Fabr); "New York" (Walk.). According to Walker's description, this is closely allied, if not identical, with bracata, Sanborn.

Smicra nigricornis, Fabr. (Chalcis) Ent. Syst. Suppl. p. 243.

Hab.-North America. This seems also closely allied to bracata, the short, meagre description of Fabricius applying much better to this latter species, than does that of maculata.

Smicra punctata, Fabr. (Chalcis) Ent. Syst. ii, p. 196. Sichel (Conura) Ann. Soc. Fr. 4 sér. v, p. 392.- "Q.-Yellow; antenuæ black, scape yellow; three triangular spots on disk of mesothorax, large spot on apex of scutellum, and a transverse fascia on each side of pleura, black; abdomen yellow with luscous spots; base and tips of posterior femora (which are 12-dentate), and a 
spot near inferior margin, base and tips of their tibiæ, and tips of tarsi, black; wings hyaline, costa yellow; apex of scutellum emarginate, subbilobate. Length 8 mill."

Hab.-West Indies (Fabr.); Mexico (Sichel).

Smicra Pylas, Walker, Entomologist, p. 337 ; List Chalcid. Brit. Mus. i, p. 3.- ".+- Yellow; head behind and between ocelli black; antennæ piceous, scape yellow ; mesothorax with a marginal abbreviated band in front, a narrow dorsal stripe and a broad lateral stripe abbreviated posteriorly, black; scutellum with basal margin and an obconical dorsal spot, black; paraptera with two black spots; second segment of abdomen with an obsolete fuscous band; legs yellow; apex of tarsi fuscous; posterior coxæ spotted with black; femora with three piceous spots, armed with black teeth; wings hyaline. Length $2 \frac{3}{4}$ lines."

\section{Hab.-Mexico. Walker says this "hardly differs form punctata."}

Smicra amoena, Say, (Chalcis) Bost. Jour. Nat. Hist. i, p. 270.-“"Body yellow, slightly tinged with green; occiput and antennæ, excepting basal joint beneath, black; thorax quadrilinear with black, the intermediate lines confluent at middle and all united by a transverse line behind and by a slender transverse line at the suture of the first segment, on which the lines do not extend; scutel with a longitudinal black line; metathorax, excepting at base, black; petiole black, about one-third as long as abdomen; each segment of abdomen with a black band; pleura black, with about four yellow spots; posterior coxæ at tip, maculated band, inferior edge and tip of their femora, and tip and base of their tibiæ, black; femora about the size of abdomen, with six or eight large prominent black spines, the superior one divided into three or four. Length less than one-fifth of an inch."

Hab._- Indiana. Obtained from the pupa of a Thecla."

Smiera Lamyrus, Walker, Entomologist, p. 337.- " $q .-Y e l l o w$; head black; antennæ black, scape yellow; a subpentagonal black spot on disk of mesothorax; scutellum with two elevated teeth at apex ; petiole long and slender; abdomen yellow anteriorly, black posteriorly; posterior coxæ very long, apex piceous, as well as their trochanters; their femora with nine minute black teeth; their tibiæ piceous at apex; wings obscure fuscous, apex subhyaline. Length 3 lines."

Hab.-Mexico. This seems closely allied to miranda, which has the whole of mesothorax and the scutellum except apical margin black and the lower and lateral margins of face yellow.

Smiera captiva, Smith, Trans. Ent. Soc. Lond. 3 ser. i, p. 42.—" $q-$ Yellow ; flagellum rufo-fuscous, tips of mandibles ferruginous; a black vase shaped outline on disk of mesothorax, and a black line each side; transverse black line at base of scutellum, the latter with a pear shaped spot on middle and an angular spot at lateral margins; pectus black at base of coxæ and an oblong black spot beneath wings; wings hyaline; apex of posterior coxæ, a brown spot on femora above and two on their sides beneath ; base and apex of tibiæreddishbrown; margins of the abdominal segments narrowly bordered with reddishbrown; widening into spots at sides and on middle. Length 3 lines."

Hab.-Panama. 
Smicra seutellaris, Sichel (Conura), Ann. Soc. Ent. Fr. 4 sér. v, p. 388, 1865.- "O.--Entirely yellow; apical half of antennæ, femoral teeth and apical joint of posterior tarsi, black ; mesothorax transversely striated ; scutellum emarginate at apex, subbilobate; posterior femora with eight acute teeth; wings yellowish-hyaline. Length 13 mill."

Hab.-Orizaba, Mexico.

Genus CHALCIS, Fabr.

Posterior femora black, with a yellow stripe above and at base beneath ; abdomen clothed with golden pubescence...

pubescens.

Posterior femora black, with a white or yellow spot at tips;

Tegulæ black, with posterior margin narrowly white..............comitator.

Tegulæ entirely white or yellow .............................................. ovata.

Posterior femora yellow on outer side, with large black discal spot....robusta.

Posterior femora yellow on outer side, with a black spot at tips beneath

tegularis.

Posterior femora ferruginous, with a yellowish spot at tips:

Four anterior legs yellow-ferruginous, with yellow spots; posterior coxæ black....

coloradensis.

Four anterior legs black, varied with yellow ; posterior coxæ red..pedalis.

\section{Chalcis pubescens.}

Chalcis pubescens, Walker, Notes on Chalcidæ, iii, p. 47.

Hab.-Mexico. (Prof. Sumichrast.) One $q$ specimen.

\section{Chalcis comitator.}

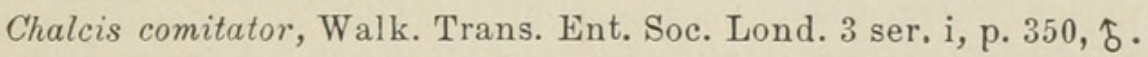

Hab.-Mexico. (Prof. Sumichrast.) One $q$ specimen.

\section{Chaleis ovata.}

Chalcis ovata, Say, Long's Second Exped. ii, p. 326, (1824).=annulipes, Walk. Ent. Mag. ii, p. 29, $\delta$ ㅇ, (1835).=incerta, Cress. Proc. Ent. Soc. Phil. iv, p. 101, $(1865)=$ ? minuta, Linn. Syst. Nat. 952 ; Fabr. Ent. Syst. ii. p. 195.=? Leucospis integra, Hald. Proc. Acad. Nat. Sci. ii, p. 53.

Hab.-United States; Mexico; West Indies. Forty-five $\hat{q}$ specimens examined. Size variable (.14-.28 inch); the pubescence varies from whitish to bright golden, sometimes tolerably dense, sometimes scarcely perceptible; apex of scutellum generally rounded, sometimes bituberculate, occasionally more or less emarginate; tegulæ white or yellow; wings generally hyaline, sometimes slightly dusky; legs variable in color, the four anterior femora sometimes black, with tips ouly white or yellow, sometimes white or yellow with base only black; their tibiæ sometimes entirely white or yellow, but generally more or less black behind; spot at tips of posterior femora tolerably constant in size, but varies in color from white to yellow; their tibiæ sometimes entirely white or yellow behind, generally with a median black band, which is occasionally narrow and interrupted, sometimes very broad, leaving only a white or yellow spot near base and at apex; their tarsi 
white or yellow, with the last or two last joints black; abdomen more or less pubescent at apex with silvery white or golden hairs.

\section{Chalcis robusta.}

Chalcis robusta, Cress. Proc. Ent. Soc. Phil. iv, p. 101.

Hab.-Cuba. Four specimens.

5. Chaleis tegularis, n. sp.

Q.-Black, sides of face with dense silvery pubescence; labrum and base of scape beneath yellow; apex of flagellum ferruginous; thorax immaculate, large, with regular, dilated punctures; scutellum produced, apex bidentate and fringed with whitish pubescence; metathorax coarsely reticulated; tegulæ pale hyaline; legs lemon-yellow, posterior coxæ above, apical half of their femora within, a spot on outside beneath near apex, as well as the row of minute teeth, black; posterior tibiæ black, with a pale yellow stripe behind; posterior tarsi dull ferruginous; abdomen short, ovate, smooth and shining, immaculate, sides and apex with pale pubescence. Length .20 inch.

Hab.-Texas. (Belfrage.) One specimen. Distinguished at once from ovata and robusta by the posterior femora being entirely yellow on outer side, except black spot at extreme tips.

\section{Chateis coloradtensis, n. sp.}

$\}$--Black, densely punctured, clothed with a short golden sericeous pubescence ; scape pale beneath ; thorax with regular, dilated punctures; apex of scutellum emarginate; tegulæ yellowish-white; wings hyaline, iridescent; legs ferruginous, coxæ black, four anterior knees, tips of their tibiæ, their tarsi, spot at tip of posterior femora, a band near base of their tibiæ and another at tips, pale yellow; femoral teeth small, numerous and black; abdomen short ovate, smooth and polished, apical segments clothed with pale golden pubescence. Length .20 inch.

Hab.-Colorado. One specimen.

7. Chalcis pedalis, $\mathrm{n} . \mathrm{sp}$.

․-Head and thorax black, with pale sericeous pubescence; thorax with large, regular, dilated punctures, apex of scutellum subdentate; tegulæ white; wings hyaline; four anterior legs black, apex of their femora, their tibiæ at base, apex and within, and their tarsi except apical joints, whitish; posterior legs ferruginous, spot at tip of femora above and a spot at base and apex of their tibiæ behind, white; abdomen as long as head and thorax, black, immaculate, polished, apex pubescent. Length .23 inch.

Hab.-Texas. (Belfrage.) One specimen. Closely allied to coloradensis, which has differently colored legs.

The following species have not been identified :-

Ghaleis pendator, Walk. Trans. Ent. Soc. Lond. 3 ser. i, p. $351, \delta$. Hab.-San Domingo.

Chalcis restituta, Walk. Trans. Ent. Soc. Lond. 3 ser. i, p. 351, . Hab.-Jamaica.

Ghalcis compacta, Walk. Jour. Ent. i, p. $183, \hat{\delta}$.

Hab.-Orizaba, Mexico. 


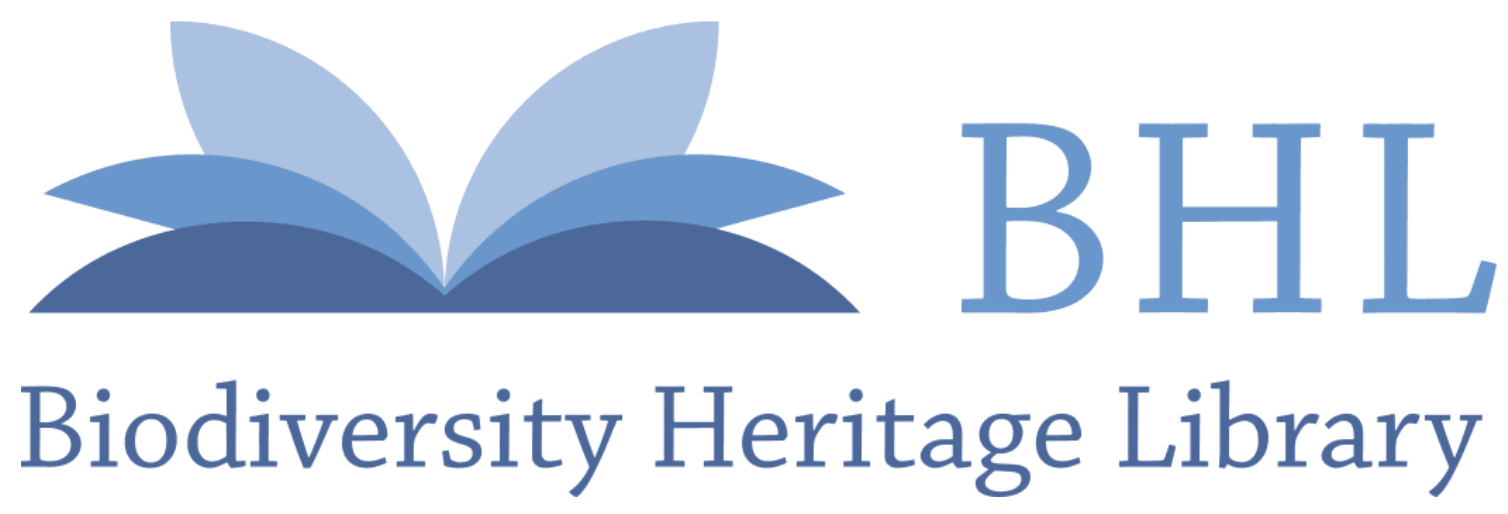

Cresson, E. T. 1872. "Synopsis of the North American species belonging to the genera |Leucospis|, |Smicra| and |Chalcis|." Transactions of the American Entomological Society 4, 29-60.

View This Item Online: https://www.biodiversitylibrary.org/item/32381

Permalink: https://www.biodiversitylibrary.org/partpdf/37711

\section{Holding Institution}

Smithsonian Libraries

\section{Sponsored by}

Smithsonian

\section{Copyright \& Reuse}

Copyright Status: NOT_IN_COPYRIGHT

This document was created from content at the Biodiversity Heritage Library, the world's largest open access digital library for biodiversity literature and archives. Visit BHL at https://www.biodiversitylibrary.org. 